\title{
Annual, seasonal and spatial variation of abundance of the shrimp Artemesia longinaris (Decapoda: Penaeoidea) in south-eastern Brazil
}

\author{
Rogério C. Costa* $*^{\ddagger}$, Adilson Fransozo ${ }^{\dagger}$, Antonio L. Castilho ${ }^{\dagger}$ and Fúlvio A.M. Freire ${ }^{\dagger}$ \\ NEBECG (Group of Studies on Crustacean Biology, Ecology and Culture). *Departamento de Zoologia, Setor de Ciências Biológicas, \\ Universidade Federal de Curitiba, UFPR, 81531-980, Curitiba, Paraná, Brazil. ${ }^{\dagger}$ Departamento de Zoologia, Instituto de Biociências, \\ Universidade Estadual Paulista, 18.618.000 - Botucatu, s/n São Paulo, Brazil. \\ ${ }^{\ddagger}$ Corresponding author, e-mail: rogeriocosta@fc.unesp.br
}

\begin{abstract}
The influence of several environmental factors on the abundance and spatial-temporal distribution of the shrimp Artemesia longinaris were investigated from January 1998 to December 1999 in the Ubatuba region of São Paulo State, Brazil. Collections were performed monthly in the bays of Ubatumirim (UBM), Ubatuba (UBA) and Mar Virado (MV). Six sampling transects were established in each bay, four were parallel to the shore line, and two were next to the rocky shores. A commercial shrimp fishing boat equipped with two 'double-rig' nets was used. A total of 11,503 individuals was collected, including 1633 from UBM, 6344 from UBA and 3526 from MV. The majority of the captured specimens came from the deeper areas (15 to $20 \mathrm{~m}$ ) with high salinity (34 to $36 \mathrm{ppt}$ ). The highest abundance of $A$. longinaris in Ubatuba bay was recorded in areas where fine and very fine sand comprised more than $70 \%$ of the sediment. Moreover, the abundance of A. longinaris followed a seasonal trend, being higher during the summer, when intrusions of cold South Atlantic Coastal Waters (SACW) are frequent. Thus, type of sediment, temperature and salinity are determinant factors in the distribution of $A$. longinaris in the studied region.
\end{abstract}

\section{INTRODUCTION}

Shrimp fisheries in south-eastern Brazil target the most profitable species, such as the pink shrimps Farfantepenaeus brasiliensis (Latreille, 1817) and F. paulensis (Pérez-Farfante, 1967), the white shrimp Litopenaeus schmitti (Burkenroad, 1938) and the seabob shrimp Xiphopenaeus kroyeri (Heller, 1862). Modifications of the scientific names were following Pérez-Farfante \& Kensley (1997). The increases of the fishing fleet and the decrease in landings of commonly exploited species have contributed to the expansion of the Artemesia longinaris Bate, 1888 fishery (D'Incao et al., 2002; Costa et al., 2004). The geographical distribution of this species is restricted to the western Atlantic, being recorded from Atafona (Rio de Janeiro, Brazil) to the province of Chubut, Argentina. This shrimp lives exclusively in the marine environment throughout its life cycle (Boschi, 1969).

Dall et al. (1990) reported several environmental factors that might be fundamental determinants of the spatial and temporal distribution of penaeid shrimps, such as type of sediment, salinity, depth and temperature.

Little is known about the biology of A. longinaris along the Brazilian coast (Fransozo et al., 2004). Several studies have been conducted in Argentinean waters, where this species is important, not only for commercial fisheries, but also as major components of marine food webs (Boschi, 1963, 1969). However, the scope of these studies is limited to faunistic surveys and geographical distribution patterns (Boschi et al., 1992; D'Incao, 1995; Nakagaki et al., 1995; Boschi, 2000; Costa et al., 2000, 2003) and some aspects of population biology (Nascimento, 1981;
Ruffino, 1991). Concerning ecological aspects, Fransozo et al. (2004) described the seasonal abundance patterns of this species in Ubatuba region of São Paulo State. Nevertheless, the spatial and temporal distribution of $A$. longinaris off the Brazilian coast is still poorly understood.

The goal of the present study is to characterize the spatial and temporal distribution patterns of A. longinaris in three bays in the Ubatuba region, south-eastern Brazil, as well as to correlate these patterns with key abiotic factors, namely salinity, temperature, depth, sediment texture, and organic matter content.

\section{MATERIALS AND METHODS}

Shrimps were collected monthly from January 1998 to December 1999 at Mar Virado (MV), Ubatuba (UBA) and Ubatumirim (UBM) Bays, in the Ubatuba region, São Paulo State. Each bay was divided into six sub-areas (transects) selected for their position relative to the bay inlet, the presence of rocky walls or beaches along the boundaries, the fresh water inflow, and the proximity of offshore water, depth and sediment texture. Four transects were established at mean depths of 5 (IV), 10 (III), 15 (II)

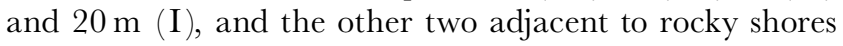
(one exposed and one sheltered shore, transects V and VI, respectively) (Figure 1). A shrimp fishing boat equipped with two double rig nets (mesh size $20 \mathrm{~mm}$ and $15 \mathrm{~mm}$ in the cod end) was used for trawling. The transects were trawled over a 30 -min period.

Salinity (ppt) and temperature $\left({ }^{\circ} \mathrm{C}\right)$ were measured in bottom-water samples, obtained each month for each 


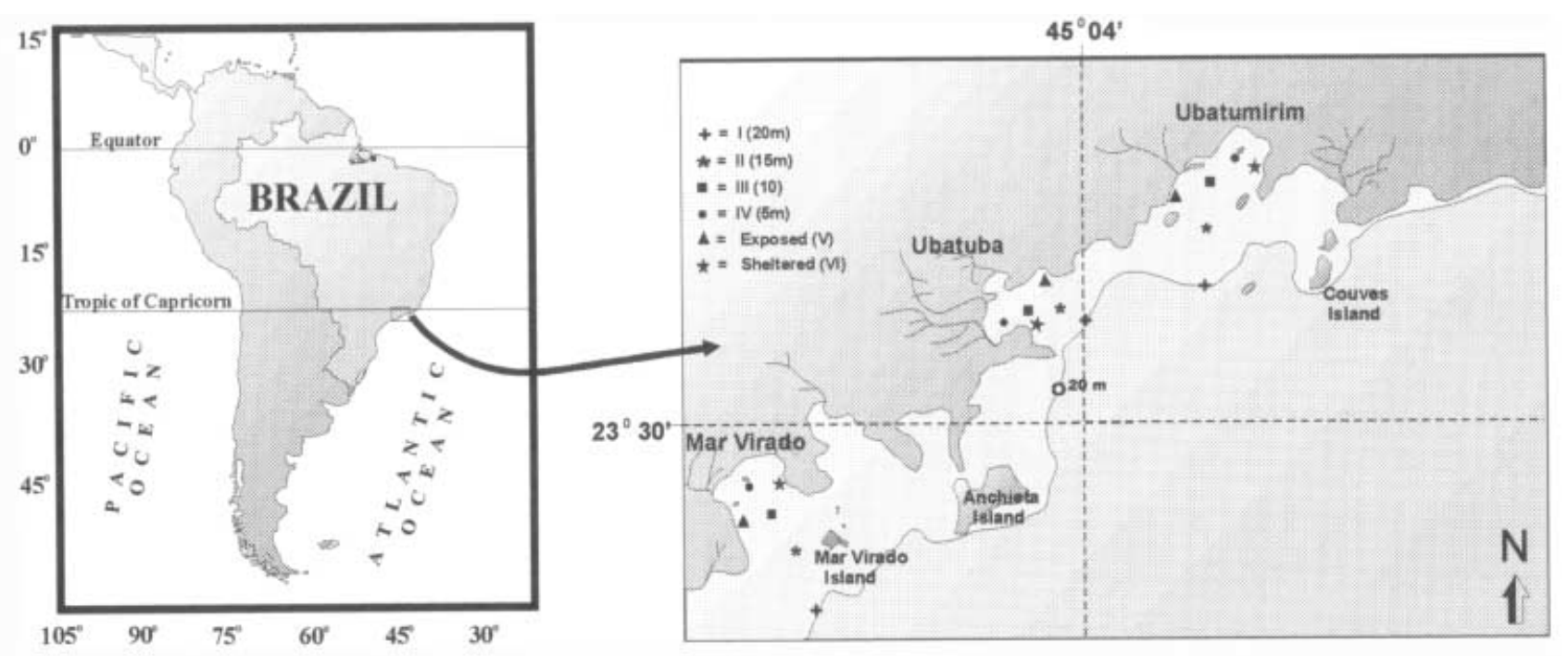

Figure 1. Map of the region indicating localities of collection.

Table 1. Monthly catch of Artemesia longinaris in each bay during 1998 and 1999 and total catch by season. Results of the analysis of variance are shown for each season. Values followed by the same small letter in the column are not statistically different (P $>0.05)$.

\begin{tabular}{|c|c|c|c|c|c|c|c|c|c|}
\hline \multirow[b]{3}{*}{ Months } & \multicolumn{6}{|c|}{ Bays } & \multirow{2}{*}{\multicolumn{2}{|c|}{ Total }} & \multirow{3}{*}{$\begin{array}{c}\text { Season } \\
\text { Total }\end{array}$} \\
\hline & \multicolumn{2}{|c|}{ UBM } & \multicolumn{2}{|c|}{$\mathrm{UBA}$} & \multicolumn{2}{|c|}{ MV } & & & \\
\hline & 1998 & 1999 & 1998 & 1999 & 1998 & 1999 & 1998 & 1999 & \\
\hline January & 726 & 176 & 4325 & 44 & 1729 & 72 & 6780 & 292 & Summer \\
\hline February & 69 & 97 & 1031 & 72 & 240 & 380 & 1340 & 549 & 205 \\
\hline March & 85 & 2 & 110 & 22 & 5 & 20 & 200 & 44 & $\mathrm{a}$ \\
\hline April & 26 & 18 & 234 & 70 & 40 & 223 & 300 & 311 & Autumn \\
\hline May & 8 & 19 & 17 & 0 & 27 & 119 & 52 & 138 & 313 \\
\hline June & 28 & 84 & 40 & 145 & 143 & 72 & 211 & 301 & $\mathrm{~b}$ \\
\hline July & 15 & 47 & 7 & 10 & 101 & 132 & 123 & 189 & Winter \\
\hline August & 6 & 7 & 8 & 6 & 48 & 23 & 62 & 36 & 428 \\
\hline September & 0 & 3 & 1 & 1 & 7 & 6 & 8 & 10 & c \\
\hline October & 0 & 5 & 1 & 7 & 3 & 6 & 4 & 18 & Spring \\
\hline November & 3 & 17 & 20 & 24 & 14 & 24 & 37 & 65 & 557 \\
\hline December & 11 & 181 & 4 & 145 & 10 & 82 & 25 & 408 & $\mathrm{c}$ \\
\hline Total & 977 & 656 & 5798 & 546 & 2367 & 1159 & 9142 & 2361 & 11503 \\
\hline
\end{tabular}

MV, Mar Virado; UBA, Ubatuba; UBM, Ubatumirim.

transect using a Nansen bottle. An ecobathymeter coupled with a GPS (Global Positioning System) was used to record depth at sampling sites. Sediment samples were collected in each season with a $0.06 \mathrm{~m}^{2}$ Van Veen grab. In the laboratory, the sediment was dried at $70^{\circ} \mathrm{C}$ for $72 \mathrm{~h}$ in an oven. For the analysis of grain size composition, two $50 \mathrm{~g}$ sub-samples were separated, treated with $250 \mathrm{ml}$ of a $\mathrm{NaOH} 0.2 \mathrm{~N}$ solution and stirred for $5 \mathrm{~min}$ to release silt and clay particles. Sub-samples were then rinsed on a 0.063-mm sieve.

Sediments were sieved through $2 \mathrm{~mm}$ (gravel);2.0-1.0 mm (very coarse sand); $1.0-0.5 \mathrm{~mm}$ (coarse sand); $0.5-0.25 \mathrm{~mm}$ (medium sand); $0.25-0.125 \mathrm{~mm}$ (fine sand); $0.125-$ $0.063 \mathrm{~mm}$ (very fine sand), and smaller particles classified as silt-clay. Cumulative particle size curves were plotted using the phi-scale, phi values corresponding to 16 th, 50th, 84th percentiles were read from the curves to determine the mean diameter of the sediment. This was calculated according to the formula $\mathrm{Md}=\left(\varphi_{16}+\varphi_{50}+\varphi_{84}\right) / 3$, after that, the phi was calculated from the formula $\varphi=-\log _{2} \mathrm{~d}$, where $\mathrm{d}=$ grain diameter $(\mathrm{mm})$ (see Hakanson \& Jansson, 1983, and Tucker, 1988).

The organic matter content $(\%)$ was obtained by ashweighing: three aliquots of $10 \mathrm{~g}$ each per transect, placed in porcelain crucibles for $3 \mathrm{~h}$ at $500^{\circ} \mathrm{C}$, then the samples were weighed again (see Mantelatto \& Fransozo, 1999).

Graphic representation of sediment texture was performed by plotting a triangular diagram using the three most representative granulometric classes, as in Magliocca \& Kutner (1965). Granulometric Class A corresponds to sediments in which intermediate sand (IS), coarse sand (CS), very coarse sand (VCS) and 
Table 2. Groups of granulometric fractions, mud contents (\% silt-clay), mean values of organic matter content (OM) of the sediment (\%) and number of individuals $(\mathcal{N})$ of the Artemesia longinaris at each transect in each sampled bay, from 1998 to 1999.

\begin{tabular}{|c|c|c|c|c|c|c|c|c|c|c|c|c|}
\hline \multirow[b]{3}{*}{ Transects } & \multicolumn{12}{|c|}{ Bays } \\
\hline & \multicolumn{4}{|c|}{ Ubatumirim } & \multicolumn{4}{|c|}{ Ubatuba } & \multicolumn{4}{|c|}{ Mar Virado } \\
\hline & Group & $\%$ mud & $\mathrm{OM} \%$ & $\mathrm{~N}$ & Group & $\%$ mud & OM \% & $\mathrm{N}$ & Group & $\%$ mud & OM \% & $\mathrm{N}$ \\
\hline I & $\mathrm{PA}$ & 2.6 & $2.1 \pm 20$ & 222 & $\mathrm{~PB}$ & 16.0 & $3.6 \pm 3.7$ & 1153 & PGB & 46.8 & $3.0 \pm 3.1$ & 1137 \\
\hline II & $\mathrm{PBC}$ & 23.9 & $3.4 \pm 17$ & 197 & $\mathrm{~PB}$ & 21.2 & $4.2 \pm 2.6$ & 3926 & $\mathrm{PG}$ & 75.3 & $4.6 \pm 2.1$ & 1991 \\
\hline III & $\mathrm{PBC}$ & 35.7 & $5.2 \pm 2.9$ & 1181 & PCB & 61.9 & $8.0 \pm 3.9$ & 134 & $\mathrm{PC}$ & 88.3 & $5.4 \pm 2.2$ & 163 \\
\hline IV & PGB & 49.6 & $4.2 \pm 2.1$ & 12 & $\mathrm{PC}$ & 76.3 & $5.7 \pm 2.8$ & 1 & $\mathrm{PG}$ & 81.2 & $5.6 \pm 1.7$ & 101 \\
\hline V & $\mathrm{PB}$ & 22.2 & $2.4 \pm 1.5$ & 16 & PCB & 47.3 & $7.5 \pm 4.8$ & 1129 & $\mathrm{PC}$ & 79.7 & $4.2 \pm 3.3$ & 107 \\
\hline VI & $\mathrm{PBC}$ & 33.4 & $4.2 \pm 2.4$ & 5 & PCA & 36.8 & $6.1 \pm 4.1$ & 1 & PCB & 64.4 & $4.4 \pm 3.4$ & 27 \\
\hline Total & & & & 1633 & & & & 6344 & & & & 3526 \\
\hline
\end{tabular}

PA, prevalence in sediments of intermediate sand + coarse sand + very coarse sand and gravel; PB, prevalence of fine sand + very fine sand; PC, prevalence of silt and clay.
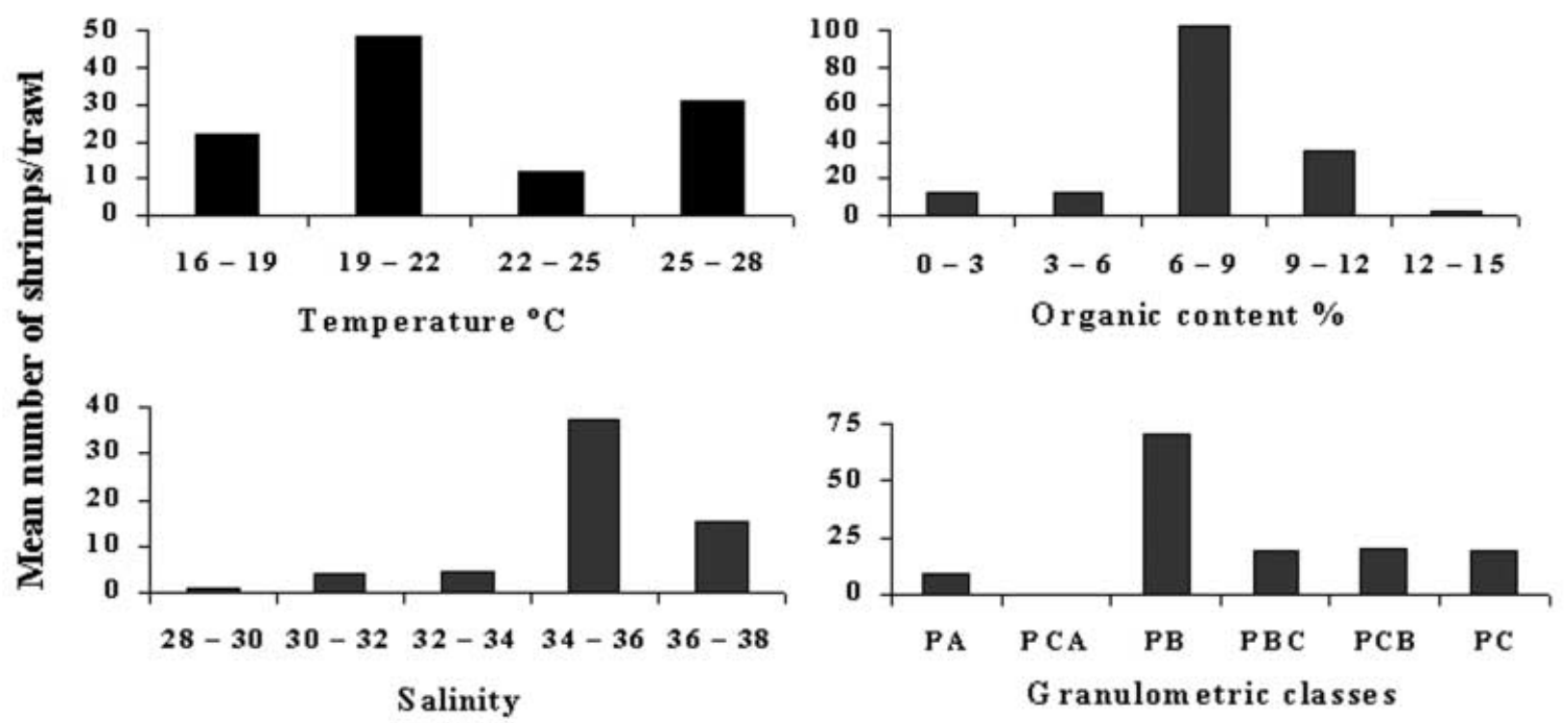

Figure 2. Distribution of the mean number of shrimps in each class of the abiotic variable per trawl with varying environmental factors (temperature, organic content, salinity and granulometric classes) from 1998 to 1999.

gravel ( $\mathrm{G}>0.25 \mathrm{~mm}$ ) account for more than $70 \%$ by weight. In Class $\mathrm{B}$, fine sand (FS) and very fine sand (VFS) make up more than $70 \%$ by weight of sediment samples $(0.25-0.0625 \mathrm{~mm})$. More than $70 \%$ of sediments in Class $\mathrm{C}$ are silt and clay $(\mathrm{S}+\mathrm{C})$. These three categories are further combined to form six different groups: $\mathrm{PA}=(\mathrm{IS}$ $+\mathrm{CS}+\mathrm{VCS}+\mathrm{G})>70 \% ; \mathrm{PAB}=$ prevalence of $\mathrm{A}$ over $\mathrm{B}$ $(\mathrm{FS}+\mathrm{VFS}) ; \mathrm{PAC}=$ prevalence of $\mathrm{A}$ over $\mathrm{C}(\mathrm{S}+\mathrm{C}) ; \mathrm{PB}$ $>70 \% ; \mathrm{PBA}=$ prevalence of $\mathrm{B}$ over $\mathrm{A} ; \mathrm{PBC}=$ prevalence of $\mathrm{B}$ over $\mathrm{C}$; $\mathrm{PC}>70 \%$; $\mathrm{PCA}=$ prevalence of $\mathrm{C}$ over $\mathrm{A}$; $\mathrm{PCB}=$ prevalence of $\mathrm{C}$ over $\mathrm{B}$.

The abundance of shrimps was compared with years, bays, transects and seasons (summer, autumn, winter and spring) of the year using analysis of variance (ANOVA). The influence of environmental factors on the species abundance were evaluated by multiple linear regression and also compared through ANOVA. Data were log- transformed prior to the analysis to improve their normality (Zar, 1999).

\section{RESULTS}

The season factor was analysed independently since the interaction between season and year was found not to be significant (ANOVA, $\mathrm{F}=0.59, P>0.05$ ). A total of 11,503 individuals was collected; 9142 during the first year and 2361 during the second (interannual differences are not statistically significant, $\mathrm{F}=1.85, P>0.05)$. Overall, abundance was lower in Ubatumirim (1633), when compared with Mar Virado (3526) and Ubatuba (6344). In general, shrimp abundance varied seasonally with significant high abundance found through the summer for both years (ANOVA, $\mathrm{F}=15.94, P<0.01$ ). Lower abundance values were recorded in winter and spring (Table 1, $P>0.05$ ). 
Summer

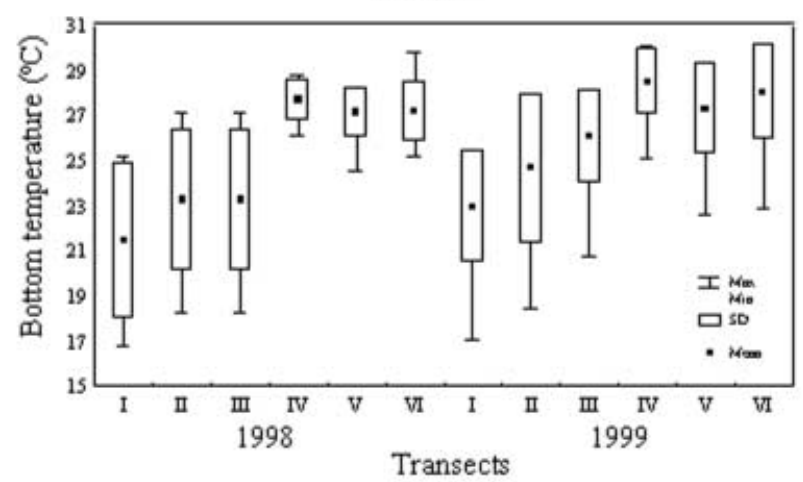

Winter

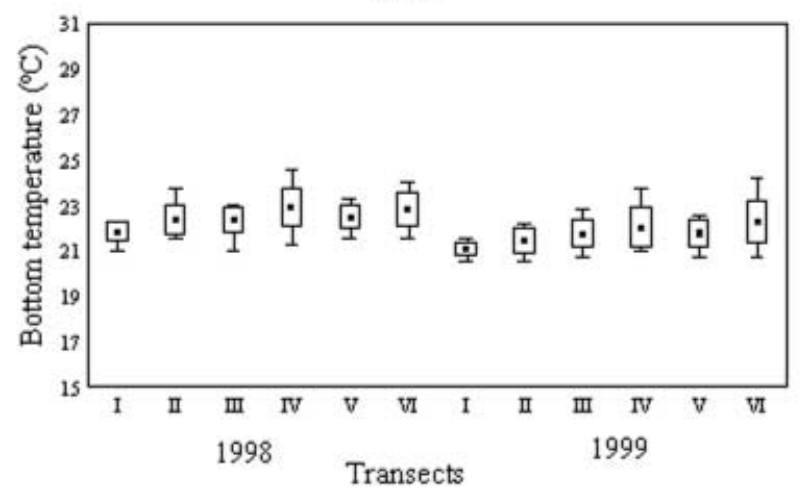

Autumn

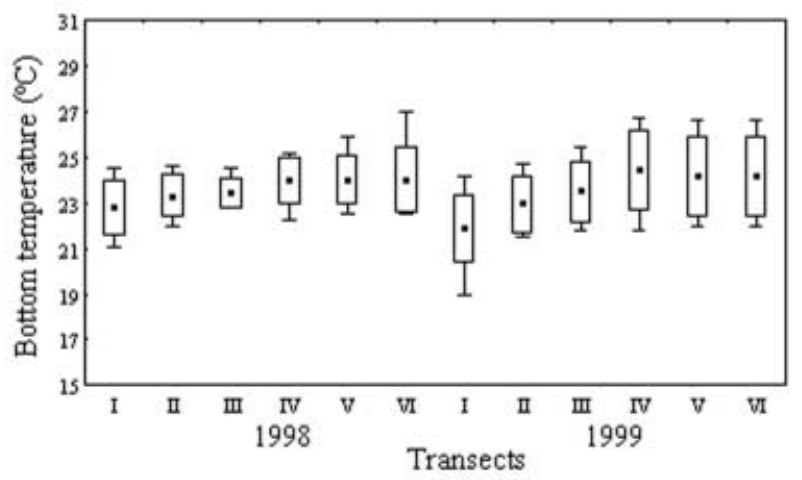

Spring

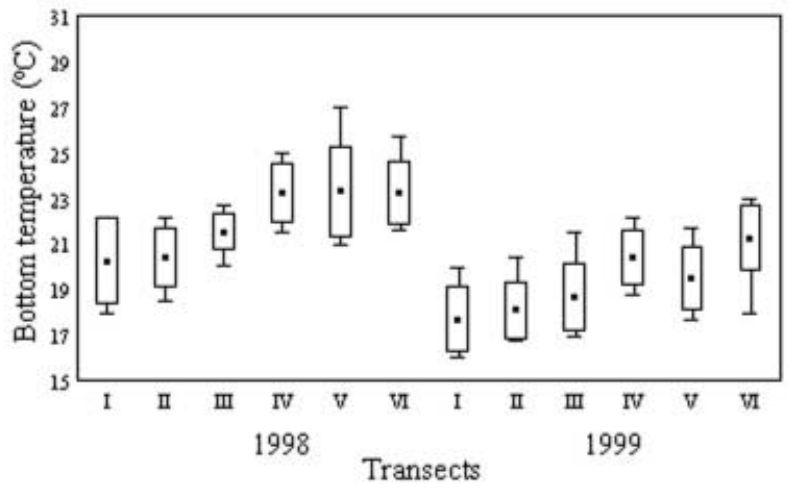

Figure 3. Box plots showing average, standard deviation, maximum and minimum temperature values for each transect and season during 1998 and 1999.

Average grain size of sediments varied from intermediate sand to silt and clay. As shown in Table 2, the amount of mud in the sediments decreased northward within the sampled areas, that is, from Mar Virado to Ubatumirim. In Mar Virado Bay, the silt + clay fraction (PC) prevailed in all transects, in Ubatuba and, especially, Ubatumirim Bay a predominance of fine and very fine sand, associated with silt and clay, was observed, except for transects IV (PG) and VI (PGA) in Ubatuba and transect I in Ubatumirim (PA).

In general, the highest values of organic matter content were obtained in transects III, IV, V and VI and the lowest values in transects I and II (Table 2). The largest number of organisms was collected at sites with intermediate levels of organic matter, i.e. between 6 and 9\% (Figure 2).

The mean depth of each transect in the bays sampled were: I $(22.2 \pm 0.6 \mathrm{~m})$, II $(16.5 \pm 1.1 \mathrm{~m})$, III $(11.6 \pm 1.1 \mathrm{~m})$, IV $(5.9 \pm 0.4 \mathrm{~m}), \mathrm{V}(9.2 \pm 1.5 \mathrm{~m})$ and VI $(6.8 \pm 2.3 \mathrm{~m})$. The vast majority of Artemesia longinaris specimens were captured in transects with fine and very fine sand substrates (PB, Figure 2), as well as in higher depths, such as transects I and II in Ubatuba and Mar Virado (Table 2). On the other hand, in Ubatumirim the highest abundance was concentrated in transect III, which was also characterized by fine and very fine sand and $13.3 \mathrm{~m}$ deep.

Approximately $80 \%$ of the organisms were captured during the summer months in both years (Table 1). There was a substantial temperature difference among transects during spring and summer. The temperature in transects I through III was lower than in transects IV through VI

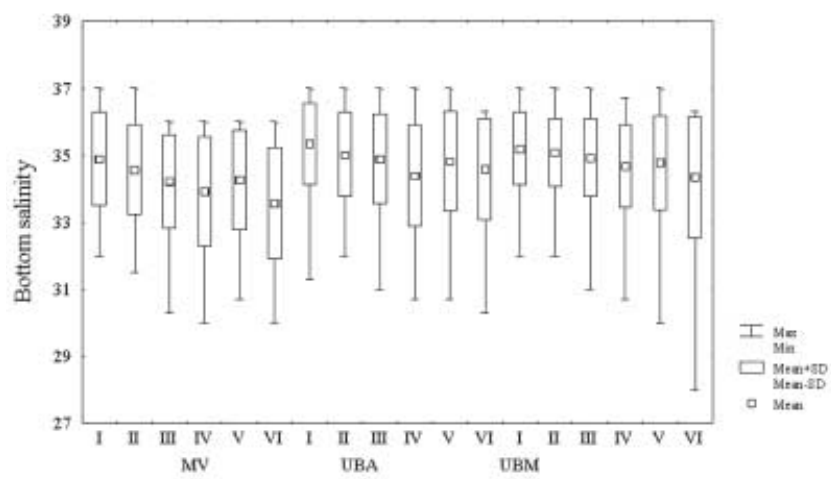

Figure 4. Box plots showing average, standard deviation, maximum and minimum salinity values for each transect at the bays during 1998 to 1999. MV, Mar Virado; UBA, Ubatuba; UBM, Ubatumirim.

(Figure 3). During the rest of the seasons, mean temperature values were homogeneous.

Variation in the average bottom salinity within each bay is shown in Figure 4. Differences in salinity between bays is substantial with the lowest mean values recorded in Mar Virado. In general, higher salinity ranges were found in transect I, whereas lower salinities were found in transects IV and VI. As shown in Figure 2, A. longinaris was recorded at higher salinities (>34 ppt) and temperatures ranging from 19 to $22^{\circ} \mathrm{C}$.

The analysis performed using the selected environmental variables and the abundance of the species 
$(\mathrm{r}=0.26 ; P=3.3 \mathrm{E}-25 ; \mathrm{F}=30.11)$ can be expressed by the following relationship:

$$
\mathrm{A}=-16.57-2.22 \mathrm{t}+7.73 \mathrm{~s}+0.30 \mathrm{o}+2.71 \mathrm{~d}+1.49 \phi
$$

where: A=abundance; $\mathrm{d}=$ depth; $\phi=\mathrm{phi} ; \mathrm{t}=$ bottom temperature; $\mathrm{s}=$ bottom salinity; $\mathrm{o}=$ organic matter.

The abiotic factors such as: sediment $(\phi) \quad(\mathrm{t}=3.74$, $P<0.001)$, salinity $(\mathrm{t}=2.56, P<0.01)$, and depth $(\mathrm{t}=9.86$, $P<0.001)$ were positively associated with the number of collected individuals. The opposite was true in the case of bottom temperatures $(\mathrm{t}=-2.09, P<0.05)$, which showed a negative association. However, no correlation was observed between organic matter content and abundance of this species $(P>0.05)$.

\section{DISCUSSION}

Water temperature, salinity and sediment texture can be considered to be key factors underlying the ecological distribution of Artemesia longinaris. This was exemplified by the high abundance of this species in areas with fine and very fine sand substrates, high salinity and low temperatures.

Higher abundance of A. longinaris in Ubatuba Bay, mainly at higher depths, is probably the result of the predominance of fine and very fine sand in that area. In Argentinean waters, A. longinaris is found at depths ranging from 2 to $125 \mathrm{~m}$, and in areas with sandy or muddy substrates (Boschi, 1963, 1969; D'Incao, 1995). However, the present study found few specimens in shallow areas, even when abiotic characteristics such as sediment type were favourable for their establishment. We suggest that the combination of lower salinity and high temperature in shallow coastal waters may prevent this species from entering areas shallower than $15 \mathrm{~m}$. This spatial pattern indicates that the life cycle of $A$. longinaris corresponds to the type III proposed by Dall et al. (1990). Species under this category are restricted to truly marine environments, with individuals usually migrating from inshore to offshore areas during their ontogeny. Costa et al. (2004) found a similar distribution pattern for Pleoticus muelleri in Ubatuba region.

Several authors have suggested that the distribution of penaeoid shrimps is strongly influenced by the texture and the organic content of the substrate (e.g. Boschi, 1963, 1969; Stoner, 1988; Dall et al., 1990; Nakagaki et al., 1995). However, no correlation was observed in the present study between organic matter content and the abundance of A. longinaris. Similar results were obtained by Costa \& Fransozo (2004) for Rimapenaeus constrictus Stimpson and by Costa et al. (2004) for P. muelleri in the same region. Somers (1987) observed that, in the Gulf of Carpentaria, Australia, juveniles of Penaeus esculentus and $P$. semisulcatus are associated with sandy and muddy sediments, respectively, and high organic matter content, although the latter preference is absent in adults of the same species. Branford (1981) found similar results for Penaeus monodon and P. indicus. On the other hand, Ruello (1973) concluded that the distribution of Metapenaeus macleayi (Haswell, 1879 ) is more affected by grain size than by the availability of food.

Other studies have suggested that salinity and temperature might play a role in determining the ecological distribution of A. longinaris. Ruffino (1991) and Boschi $(1963,1969)$ stated that this species is typical of colder regions, occurring in a temperature range from 15 to $21^{\circ} \mathrm{C}$ and salinity above $33 \mathrm{ppt}$. According to Castro-Filho et al. (1987), coastal waters (CW) influence environmental conditions in shallow waters up to $25 \mathrm{~m}$ deep. In this region, salinity is always below $36 \mathrm{ppt}$ and temperature higher than $20^{\circ} \mathrm{C}$. Another environmental factor that might influence water temperature in this region is the South Atlantic Coastal Waters (SACW), which is more prevalent during summer and late spring, when it causes temperature to decrease in deeper areas, which might occasionally reach coastal areas.

The shrimp A. longinaris, together with Pleoticus muelleri, migrates to the north shore of São Paulo State during the intrusions of cold SACW. This current occurs during the spring and/or summer months, causing a decrease in temperature to levels between 15 and $21^{\circ} \mathrm{C}$. However, the abundance of these species differed between years and seasons in the present study. Contrary to what was observed in A. longinaris, P. muelleri capture was low during 1998 ( $\mathrm{N}=376$ individuals). Conversely, in the following year, 5876 specimens were collected mostly during the spring (see Costa et al., in press). This might have been caused by the lower temperatures in the second year, particularly during the spring, when temperatures were below $19^{\circ} \mathrm{C}$. According to Castro-Filho et al. (1987) the SACW reaches a northern limit in the State of Rio de Janeiro, after which temperatures are markedly higher than in southern Brazil.

Our data suggest that $A$. longinaris can cope with more pronounced thermal oscillations and migrates further north along the Brazilian coast than P. muelleri. Thus, following the retraction of the SACW, P. muelleri starts its migration south earlier than A. longinaris. It is conceivable that $A$. longinaris and $P$. muelleri adjust their distribution in space and time according to their intrinsic physiological limitations, possibly as a result of differences in their adaptation to the resources present in tropical regions.

The authors are grateful to FAPESP for providing financial support (\#94/4878-8, \#97/12108-6, \#97/12106-3, \#9712107-0 and \# 98/3134-6). We are thankful to Dr Márcio Pie (Boston University) and Dra Maria L. Negreiros-Fransozo for their constructive comments on early drafts of the manuscript.

\section{REFERENCES}

Boschi, E.E., 1963. Los camarones comerciales de la familia Penaeidae de la costa Atlántica de la América del Sur. Boletín del Instituto de Biología Marina, 3, 1-39.

Boschi, E.E., 1969. Estudio biológico pesquero del camarón Artemesia longinaris Bate de Mar del Plata. Boletín del Instituto de Biología Marina, 18, 1-47.

Boschi, E.E., 2000. Species of decapod crustaceans and their distribution in the marine zoogeographic provinces. Revista de Investigación y Desarrollo Pesquero, 13, 7-136.

Boschi, E.E., Fischbach, C.E. \& Iorio, M.I., 1992. Catálogo ilustrado de los crustáceos estomatopodos y decapodos marinos de Argentina. Frente Marítimo, 10, A, 7-94.

Brandford, J.R., 1981. Sediment and the morphometric equation for Penaeus monodon and Penaeus indicus from the Red Sea. Estuarine, Coastal and Shelf Science, 13, 473-476. 
Castro-Filho, B.M., Miranda, L.B. \& Myao, S.Y., 1987. Condiçees hidrográficas na plataforma continental ao largo de Ubatuba: variaçes sazonais e em média escala. Boletim do Instituto Oceanográfico, 35, 135-151.

Costa, R.C. \& Fransozo, A., 2004. Abundance and ecologic distribution of the shrimp Rimapenaeus constrictus (Crustacea: Penaeidae) in the northern coast of São Paulo State, Brazil. Journal of Natural History, 38, 901-912.

Costa, R.C., Fransozo, A., Mantelatto, F.L.M. \& Castro, R.H., 2000. Occurrence of shrimp species (Natantia: Penaeidea: Caridea) in Ubatuba Bay, Ubatuba, SP, Brazil. Proceedings of the Biological Society of Washington, 113, 776-781.

Costa, R.C., Fransozo, A., Melo, G.A.S. \& Freire, F.A.M., 2003. An illustrated key for Dendrobranchiata shrimps from the northern coast of São Paulo state, Brazil. Biota Neotropica, 3, 1-12. www. biotaneotropica.org. br/v3nl

Costa, R.C., Fransozo, A. \& Pinheiro, A.P., 2004. Ecological distribution of the shrimp Pleoticus muelleri (Bate, 1888) (Decapoda: Penaeoidea) of Southeastern Brazil. Hydrobiologia, 529, 195-203.

Dall, W., Hill, B.J., Rothilsberg, P.C. \& Staples, D.J., 1990. The biology of the Penaeidae. In Advances in marine biology (ed. J.H.S. Blaxter and A.J. Southward), pp. 1-489. San Diego: Academic Press.

D'Incao, F., 1995. Taxonomia, padres distribucionais e ecológicos dos Dendrobranchiata (Crustacea: Decapoda) do litoral brasileiro. $\mathrm{PhD}$ thesis, Universidade Federal do Paraná, Curitiba (PR), Brazil.

D’Incao, F., Valentini, H. \& Rodrigues, L.F., 2002. Avaliação da pesca de camâres nas regîes Sudeste e Sul do Brasil. Atlântica, 24, 103-116.

Fransozo, A., Costa, R.C., Castilho, A.L. \& Mantelatto, F.L., 2004. Ecological distribution of the shrimp "Barba-ruça" Artemesia longinaris (Decapoda: Penaeidae) in Fortaleza Bay, Ubatuba, Brazil. Revista de Investigación y Desarrollo Pesquero, 16, $45-53$.

Hakanson, L. \& Jansson, M., 1983. Principles of lake sedimentology. London: Springer-Verlag.
Magliocca, A. \& Kutner, A.S., 1965. Sedimentos de fundo da Enseada do Flamengo, Ubatuba, SP. Contribuiçes Avulsas do Instituto Oceanográfico, 198, 1-15.

Mantelatto, F.L.M. \& Fransozo, A., 1999. Characterization of the physical and chemical parameters of Ubatuba bay, northern coast of São Paulo state, Brazil. Revista Brasileira de Biologia, 59, 23-31.

Nascimento, P.A.M., 1981. Variaçes no tamanho médio de maturação em Artemesia longinaris Bate, 1888 (Crustacea: Decapoda: Penaeidae). Naturalia, 6, 33-42.

Nakagaki, J.M., Negreiros-Fransozo, M.L. \& Fransozo A., 1995. Composição e abundância de camar̂es marinhos (Crustacea; Decapoda: Penaeidae) na Enseada de Ubatuba, Ubatuba, Brasil. Arquivos de Biologia e Tecnologia, 38, 583-591.

Pérez Farfante, I. \& Kensley, B., 1997. Penaeoid and segestoid shrimps and prawns of the world. Keys and diagnoses for the families and genera. Mémoires Muséum National d'Histoire Naturalle, 195, 1-233.

Ruello, N.V., 1973. The influence of rainfall on the distribution and abundance of the school prawn Metapenaeus macleayi in the Hunter region. Marine Biology, 23, 221-228.

Ruffino, M.L., 1991. Dinâmica populacional do camarão Artemesia longinaris Bate, 1888 (Decapoda, Penaeidae) do sul do Brasil. PhD thesis, Fundação Universidade do Rio Grande, Rio Grande, Brazil.

Somers, I.F., 1987. Sediment type as a factor in the distribution of commercial prawn species in the Western Gulf, Australia. Australian Fournal of Marine Freshwater Research, 38, 133-149.

Stoner, A.W., 1988. A nursery ground for four tropical Penaeus species: Laguna Joyuda, Puerto Rico. Marine Ecology Progress Series, 42, 133-141.

Tucker, M., 1988. Techniques in sedimentology. Oxford: Blackwell Scientific Publications.

Zar, J.H., 1999. Biostatistical analysis, 4th edn. New Jersey: Prentice Hall.

Submitted 6 Fuly 2004. Accepted 24 January 2005. 